\title{
LIABILITY OF LEGAL PERSON IN INDONESIA: A STATUTORY AND PRACTICAL REVIEW
}

\author{
Yetty Komalasari Dewi ${ }^{1}$
}

\begin{abstract}
Liability of legal persons for criminal offences has been slowly, but making its way to the legislations of Indonesia. Trends of development indicate that the liability of legal persons for criminal offences has been regulated in few regulations and will be regulated in the bill of Indonesia Penal Code that is now being drafted. Grounds of liability of legal persons indicate that it is a question of a special from of criminal responsibility, adapted to legal persons.
\end{abstract}

\section{Introduction}

In the past several years, the discussion concerning liability of legal person re-emerged. This is mainly because of the development of criminal law that, in some countries as well as in the international criminal rules, imposes criminal liability against legal persons, especially corporation. This phenomenon has encouraged me to write in this paper. This paper will discuss the conceptual framework of the legal person and its liability according to Indonesian's perspective.

\section{What Is "Legal Person"?}

The law distinguishes between a natural and legal person. A natural person is any human being, with legal capacity commencing from the time of birth. A legal person is an association of people or special-purpose fund that is recognized by law as having legal personality. ${ }^{2}$ Other source defines a legal person as a body of persons or an entity considered as having many of the rights and responsibilities of a natural person and especially the capacity to sue and be sued. ${ }^{3}$ To be a legal person is to be the subject of rights and duties. ${ }^{4}$

\footnotetext{
${ }^{1}$ Lecturer, Faculty of Law, University of Indonesia. Paper presented in The 3rd CILS International Conference on Human Security, Faculty of Law Hasanuddin University, Makasar, 26-27 November 2012.

${ }^{2}$ http://www.eurofound.europa.eu/htm, accessed on October 20, 2012.

3 Merriam-Webster, Inc., Merriam-Webster's Dictionary of Law, (US: Merriam Webster, Incorporated, 1996,) p. 286

${ }^{4}$ Bryant Smith, Legal Personality, Suspicions News Magazine, Vol. 12 No. 1, p.79-99, 80, accessed on www.antisyhster.com, October 21, 2012.
} 
Thus, legal person is commonly understood as a holder of rights and duties before the law or bearer of the rights and duties. ${ }^{5}$

Indonesia law also recognized two types of "person" or "legal person", namely: ${ }^{6}$

1. Natural person (human, individual)

2. Juristic person (artificial person, legal entity, body-corporate)

Legal person is also known as juristic persons, i.e. legally deemed to be single entities, distinct and separate from all the individuals who compose them. Juristic person/legal entity means that it can sue and be sued, hold property, conduct transactions and, incur criminal liability in their own name and on their own account (where jurisdiction so allow). ${ }^{7}$

Another understanding is that a legal person is separate legal entity. If it is a separate legal entity, it means it is different from its members. It works as a individual body. ${ }^{8}$ It can make contracts, open a bank account, can sue and be sued by others. ${ }^{9}$ The law has recognized that even if a person holds virtually all the shares, the right and obligations of the company shall be different from its members. ${ }^{10}$

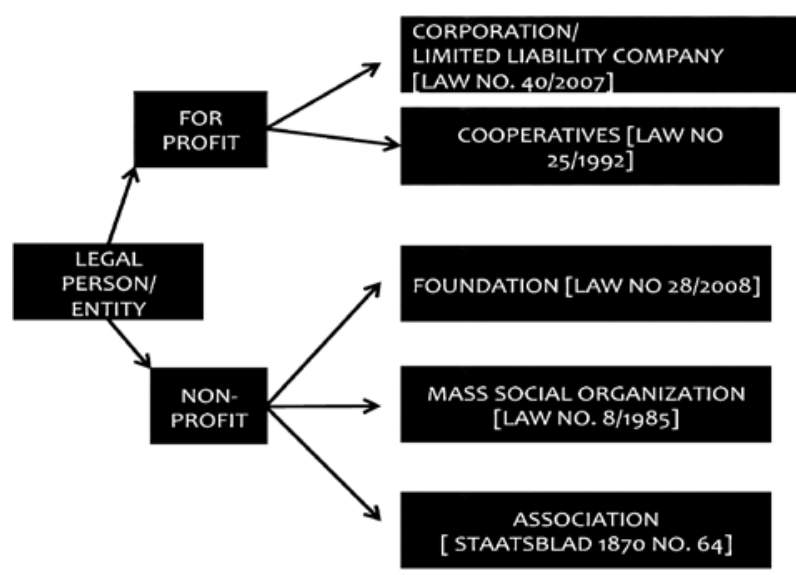

Legal person is also understood as an artificial person, meaning that it is a purely a creation of law. It is invisible, intangible and exists only in the eyes of law. It has no soul, no body, but has a position to enter or exit into a contract,

${ }^{5}$ E. Utrecht, Introduction to Indonesian Law (Pengantar Dalam Hukum Indonesia), cet. 11, (Jakarta: PT Ichtiar Baru and Sinar Harapan, 1989), p. 264.

6 L.J. van Apeldoorn, Introduction to Legal Science [Inleiding Tot De Studie Van Het Nederlandse Recht], (Jakarta: PT Pradnya Paramita, 1986), p. 203 - 204

7 Henry Campbell Black, Black's Law Dictionary, $6^{\text {th }}$ Edition, (St. Paul, Minn.: West Publishing Co., 1990), available at Black's Law Dictionary Free Online Legal Dictionary 2nd Ed, http://thelawdictionary. org, accessed on 19 October 2012.

${ }^{8}$ Nicholas James, "Separate Legal Personality: Legal Reality and Metaphor", Bond Law Review: Vol. 5: Iss. 2, Article 6 (1993), available at: http://epublications.bond.edu.au/blr/vol5/iss2/6, accessed on 20 October 2012.

${ }^{9}$ Ibid.

10 Merriam-Webster, Inc., Merriam-Webster's Dictionary of Law, (US: Merriam Webster, Incorporated, 1996,) p. 286 
to appoint a people as its employees. In short it can do every thing just like a natural person. ${ }^{11}$

The legal person is created, at least, because of two purposes; firstly if the aim or goal of its creation is for good or an ideal goal or non-profit-motive; and secondly, if the aim or goal of its creation is for profit-motive. ${ }^{12}$ Types of legal entities or artificial persons may vary from foundation, mass-organization, association with legal entity status, cooperative to corporation. ${ }^{13}$

As a comparison, in France, legal entities include private law legal entities, both for profit (company, partnership), and non-profit (association, political parties, trade union, etc), and public law legal entities [except State and public service delegation]. ${ }^{14}$

\section{The Corporation as a "Legal Person".}

When considering the criminal liability of the corporation itself, the definition of "corporation" is of major importance, simply because it determines the situations in which, and the extent to which, the law will apply.

United States defines corporation as a group of people who get a charter granting them as a body certain of the legal powers, rights, privileges, and liabilities of an individual, distinct from those of the individuals making up the group..$^{15}$ Other definition is an entity having authority under law to act as a single person distinct from the shareholders who own it and having rights to issue stock and exist definitely. ${ }^{16}$

In United Kingdom, a corporation is defined as a legal entity, created under the authority of a statute, which permits a group of people, as shareholders, to apply to the government for an independent organization to be created, which then pursues set objectives, and is empowered with legal rights usually only reserved for individuals, such as to sue and be sued, own property, hire employees or loan and borrow money. ${ }^{17}$

In German, a corporation (aktiengeselleschaft, abbreviated AG) is limited by shares owned by shareholders and may be traded on stock market. ${ }^{18}$

Article. L.225 -1 of France Commercial Code states that the corporation (Société anonyme, S.A.) is a commercial company which has legal personality and the liability of the members (at least seven shareholders) is limited to the contributions made. ${ }^{19}$

11 Blacks Law Dictionary, 7th Edition

12 Black's Law Dictionary, 6th Edition, p. 791

13 Ibid.

${ }^{14}$ Corporate Criminal Liability -- A Discussion Paper by Professor Anne-Marie Boisvert, Faculty of Law University of Montreal, 1999, at www.law.ualberta.ca/alri/ulc/99pro/ecrliab.htm, accessed on October $20,2012$.

${ }^{15}$ Noah Webster, Webster's New Twentieth Century Dictionary: Unabridged, $2^{\text {nd }}$ Ed, (New York, USA: 1983, Simon \& Schuster), p.409

${ }^{16}$ Black's Law Dictionary, $7^{\text {th }}$ Ed, (St. Paul Minnesota: West Group, 1999), p. 341.

17 http://www.duhaime.org, accessed on 21 October 2012. See also: Paul Davies, Gower's Principles of Modern Company Law, 6th Ed., (London: Sweet \& Maxwell, 1997), p. 3

18 Caroline Fohlin, The History of Corporate Ownership and Control in Germany, November 2005, http://www.nber.org/chapters/c10271.pdf, accessed on 21 October 2012.

${ }^{19} \mathrm{http}: / /$ ec.europa.eu/enterprise/policies/sme/business-environment/ annexes accounting report 2011/france en.pdf, accessed on October 19, 2012. 
Netherlands' law recognizes two different types of corporations: the N.V. (Naamloze Vennootschap) and the B.V. (Besloten Vennootschap). Both the N.V. and B.V. are separate legal entities, separate from their shareholders, with a capital divided into shares. ${ }^{20}$

A corporation, or Indonesian Limited Liability Company or Indonesian Perseroan Terbatas (PT), is a separate legal entity (or legal person). Indonesian Company Law defines Limited Liability Company (corporation, "perseroan terbatas") as a legal entity which is an association of capital, established pursuant to an agreement, which engages in business activities, with an authorized capital which is completely divided into shares and meets the requirements stipulated in the Limited Liability Company Act and its implementing regulations. ${ }^{21}$

From the above definitions, it can be concluded that corporations are treated as artificial persons created by the state that can sue or be sued in their own names, enter into and enforce contracts, hold title to and transfer property, and be found civilly and criminally liable for violations of law.

\section{What Is Liability?}

Liability is the quality or state of being legally obligated or accountable ${ }^{22}$ or is the state of being liable, which is, legally bound, as to make good any loss or damage that occurs in a transaction. ${ }^{23}$

Thus, liability refers to legal obligation to compensate a person who has suffered harm as a result of another person's wrongful actions, or failure to act when legally required to do so. In other words, liability incurs when violates a person's legal rights, or a failure to perform a legal duty owed to a certain person or to society as a whole. ${ }^{24}$ Wrongful actions must have violated the victim's rights. Legal obligation include:
a. Crime
b. Breach of contract
c. Unlawful act

\section{Source of Liability}

Legal liability arises from two sources of law, namely:

1. Civil Code, i.e. Civil Liability including:

a. liability arises from a breach of contract

b. liability arises from an unlawful act (wrongful act)

2. Criminal Code, i.e. Criminal Liability.

\footnotetext{
${ }^{20}$ See Burgelijke Wetboek Art. 2:64(1)/175(1).

${ }^{21}$ Art. 1 (1) of Law No. 40/2007 concerning Limited Liability Company.

22 Bryan A. Gardner, ed., Black's Law Dictionary, $2^{\text {nd }}$ Edition, (St. Paul, Minn.: West Group, 2001), p.932.

${ }^{23}$ Noah Webster, Webster New Twentieth Century Dictionary of the English Language Unabridged, $2^{\text {nd }}$ Edition, (New York: Simon \& Schuster, 1983), p. 1041 - 1042

${ }^{24}$ http://www.businessdictionary.com/definition/liability.html, accessed on 20 October, 2012.
} 


\section{Civil Liability}

The civil liability is a form of juridical liability which consists in an obligations relation based on which a person has the obligation to repair the prejudice caused to another person by his deed, or in certain cases stipulated by the law, the prejudice he is responsible for. ${ }^{25}$

Indonesian civil law has long been recognized that a legal person (as an independent legal subject; persona-standi-in-judicio) could perform an unlawful act (onrechtmatige daad; ${ }^{26}$ wrongful act or tort ${ }^{27}$ ). Therefore, in civil law legal entity (legal person) may be deemed guilty of an wrongful act, the members of the board of directors as well as natural persons. The act including an omission whereby a person do not carry out his/her legal duties; and commission whereby a person commit act not legally able to perform.

The third party who suffered damages may claim for damages. There are two types of damages, i.e. actual damages and punitive damages. Actual damages is a compensation for the victim or third party for his/her actual losses. Punitive damages is a compensation designed to punish people and organizations so that others are deterred from committing the same wrongful act.

Moreover, a person is not only responsible for the damages by his own deed, but also for damages caused by the deeds of persons under his responsibility [Article 1367 of the Indonesian Civil Code]. Under the doctrine of $r e$ spondeat superior ${ }^{28}$ or vicarious liability, an employer can be held liable for the negligent acts of employees while they are acting on the employer's behalf. ${ }^{29}$ However, in order to held employer liable, at least two criteria have to be satisfied, namely: the worker must be an employee and the employee must be acting within the scope of employment when the negligent act occurred.

It has to be borne in mind that a parent can be held liable if a child uses a dangerous weapon to injure someone.

\section{Criminal Liability.}

Criminal law involves prosecution by the government of a person for an act that has been classified as a crime, i.e. any act or omission (of an act) in violation of a public law forbidding or commanding it. ${ }^{30}$

${ }^{25}$ Bogdan Olteanu, Civil Liability in the Internal Law of the European Union Member States, available at http://www.juridicaljournal.univagora.ro, accessed on 20 October 2012.

26 Art. 6:162 paragraph 2 of the Dutch Civil Code defines it as a violation of a right and an act or omission in breach of a statutory duty with which, according to unwritten law in society, and all subject to the presence of a justification. Tort is the main reservoir. Available at: http://www.encyclo.nl/lokaal/10752, accessed on 19 October 2012.

27 Tort is defined as a wrongful act, other than a breach of contract, that injures another and for which the law permits a civil (noncriminal) action to be brought. Relief may be obtained in the form of damages or an injunction. The term derives from Latin tortum, meaning "something twisted, wrung, or crooked." Assault, defamation, malpractice, negligence, nuisance, product liability, property damage, and trespass are all (apart from their potentially criminal and contractual aspects) torts. Source: Concise Encyclopedia, at http://www.merriam-webster.com/dictionary/tort, accessed on 19 October 2012.

${ }^{28}$ [Latin, Let the master answer.] Respondeat Superior is a common-law doctrine that makes an employer liable for the actions of an employee when the actions take place within the scope of employment. See: http://legal-dictionary.thefreedictionary.com, accessed on 19 October 2012.

29 Manduchi Carla, The Introduction of Corporate "Criminal" Liability in Italy, published 16/12/2010, available at http://esameavvocato.diritto, accessed on 22 October 2012.

${ }^{30} \mathrm{http}: / /$ www.law.cornell.edu, accessed on 19 October 2012. 
Criminal liability is the culpability for acts which harm society, and which are prosecuted by the government. ${ }^{31}$ Crimes, unlike torts, requite intent. "Black letter law" requires an "actus reus"and a "mens rea." One must mean to do the act, and the act must be completed.

Corporate criminal liability is the liability imposed upon a corporation for any criminal act done by any natural person. Liability is imposed so as to regulate the acts of a corporation. ${ }^{32}$

The old maxim argues that a corporation cannot commit a criminal offense because criminal law focused on assigning moral culpability for the commission of certain acts. Thus, it was considered inappropriate that a legal person (such as a business or corporation), incapable of moral culpability, could be subjected to it.

But it is no longer entirely valid particularly in response to current crime trends in which serious criminal offences such as organized crime, corruption, money laundering, and the financing of terrorism are perpetrated through corporate entities as well as through individuals.

In criminal law, an overview of the criminal (crimes) are often associated with physical actions performed by the actors (dader). Meanwhile, the juristic person action is always manifested through human actions (directors; management).

Given the complex structures of corporate entities, it is sometimes difficult to identify a natural person who is the perpetrator of the criminal offense.

The introduction of legal provisions in domestic law that provide for liability of legal persons serves:

a) to address the difficulty of identifying the natural person who is the perpetrator,

b) to tackle serious criminal offenses perpetrated by those who try to shield their criminal conduct through the use of corporation, and

c) to target the assets of a corporation used as a front for criminal conduct

The introduction of criminal liability of a legal person may have a deterrent effect, partly because reputational damage can be very costly and partly because it may act as a catalyst for more effective management and supervisory structures to ensure compliance

\section{Attributing Liability of Legal Person.}

Attribution ${ }^{33}$ applies both to civil as well as criminal liability of natural person to legal person. As comparison, in French Law, the criminal liability of legal entities has been acknowledged since the Criminal Ordinance of 1670 and rule until French Revolution. In France, it is attributable if the offence has been committed "on their account by their organs or representatives". In other words, a legal entity may not be held liable if its manager acts on his own behalf or in his own personal interest or if the offence is committed by an employee acting on his own initiative.

The first recognition of the corporate criminal liability is found in the

${ }^{31}$ www.thelawbank.co.uk, accessed on 19 October 2012.

${ }^{32}$ http://definitions.uslegal.com, accessed on 19 October 2012.

33 Attributable has similar meaning with accountable, imputable, or chargeable. 
$R v$. Great North of England Railway [1846] where courts saw the corporation as a fiction and limitedly responsible for the outcomes of acts and decisions made, and is permissible to attach criminal liability to a corporation where the conduct constituted a public nuisance or breached of a statutory obligation. Since then, at least in common law countries, corporations have come to be held criminally responsible in a variety of settings. However, up to the present day, much has changed since the decision was rendered and this path is not universally followed. European started the other way, arguing that real human beings, natural person, not corporation, should be subjected to the denunciation of criminal law. . $^{34}$

Some legal systems still insist on the argument that only a man as a natural person is capable of expressing his will and provoking the prohibited consequences; for this reason, legal persons cannot be held liable for criminal offences. The majority of legal systems have already conformed to the demand of punishing legal persons alone for criminal offences. In these legal systems, there have been some attempts, made in positive law, to establish conditions for indirect (i. e. derivative) liability of legal persons for criminal offences, which is also a basis for the imposition of criminal sanctions. A ground for the liability of legal persons is still a criminal offence of a natural person, committed in favor of the legal person and on its account. Yet, a small number of legal systems recognize to legal persons the attribute of active subject of a criminal offence with its own will, which is a ground for their direct (autonomous, independent) liability for a criminal offence.

Part of the European reluctance to hold corporation responsible in their own right may stemmed from the political history. ${ }^{35}$ Offences and associated serious crimes are often committed through or under the cover of legal entities, such as companies or fake charitable organizations.

The liability of the natural persons who perpetrated the acts, therefore, is in addition to any corporate liability. Thus, if an individual commits crimes on behalf of a legal entity, it must be possible to prosecute and sanction them both.

Many developing countries do not recognized the criminal liability of legal entities or do so to only a very limited extent. In China, for example, Corporate criminal liability exists as a subset of what are called 'Unit Crimes'. Units include corporations, but also various entities. In 1997, revisions to the General Part of the Chinese Criminal Code allowed for unit crimes. Article 30 of the Chinese Criminal Code provides that companies, enterprises, institutions, state organs and social organizations when committing acts endangering the society shall assume criminal liability when prescribed by law. ${ }^{36}$ Chen observes that approximately 81 offences in the Criminal Code allow for corporate criminal liability. ${ }^{37}$ Later on, it was stated that there are $129 .{ }^{38}$

${ }^{34}$ G. Mueller, Mens Rea on the Corporation: A Study of the Model Penal Code Position on Corporate Criminal Liability, 1957.

35 Ron Harris, Transplantation of the Legal Discourse on Corporate Personality Theories: From German Codification to British Political Pluralism and American Big Business, 2007.

${ }^{36}$ Jianfu Chen, Chinese Law: Towards an Understanding of Chinese Law, Its Nature and Development (1999) 181.

37 Ibid.

${ }^{38}$ Liu Jiachen, 'The Legislation and Judicial Practice on Punishment of Unit Crimes in China' in Eser, Heine and Huber (eds), Criminal Responsibility of Legal and Collective Entities (1999) 71, 75. 
The criminal liability of legal entities is recognized in France, the Netherlands, and the USA. The USA has criminal law at both the state and federal level. The majority of prosecutions are brought under State criminal laws. The liability of corporations under federal criminal law is based on the doctrine of respondeat superior, or vicarious liability. Under this doctrine, corporations my be criminally liable for the illegal acts of officers, employees or agents, provide that it can be established that:

- the individual's actions were within the scope of their duties; and

- the individual's actions were intended, at least in part, to benefit the corporation

The position in relation to State criminal laws is more complex. Some states have adopted more sophisticated statutory provisions concerning corporate liability, based, in some cases, on the Model Penal Code ${ }^{39}$ State criminal laws vary in their approach to corporate criminal liability. Some States have provisions based on the Model Penal Code, which, while preserving a mechanism for imputing liability that is very similar to the vicarious liability model existing in federal criminal law, also allows a corporation to be convicted of an offence if the offence was:

authorized, requested, commanded, performed or recklessly tolerated by the board of directors or a high managerial agent acting on behalf of the corporation within the scope of his office or employment. ${ }^{40}$

Under the Federal Sentencing Guidelines Manual, 'corporate culture' considerations are taken into account in assessment of the appropriate fine and other orders to be imposed on corporate defendants. ${ }^{41}$ However, the Department of Justice is increasingly relying on 'deferred and non-prosecution agreements', which allow corporate defendants to avoid indictment at all by taking a range of steps, which usually include payment of a monetary penalty, and, more importantly for present purposes, making changes to their corporate governance. ${ }^{42}$

In Netherlands, a provision concerning general corporate criminal liability was introduced into the Dutch Criminal Code 1976. Previously, it had existed under the Act on Economic Crimes, but was of narrower application. Article 51.2 of the Dutch Criminal Code provides if a criminal offence is committed by a juristic person, criminal proceedings may be instituted and such penalties and measures as are prescribed by law, where applicable may be imposed:

(1) against the juristic person; or

(2) against those who have ordered the commission of the criminal offence, and against those in control of such unlawful behavior; or

(3) against the persons mentioned under (1) and (2) jointly.

Germany, Italy or Switzerland may often sanction legal entities but not under criminal law per se. So in Europe the problems of harmonization of laws therefore arise.

\footnotetext{
${ }^{39}$ James Gobert and Maurice Punch, Rethinking Corporate Crime (2003) 59.

${ }^{40}$ American Law Institute, Model Penal Code (1981 revision) §2.07(1)(c).

${ }^{41}$ United States Sentencing Commission, Federal Sentencing Guidelines Manual (2006) §8C2.5(b)

(1) (Sentencing Guidelines) available at <http://www.ussc.gov> at 14 October 2007

${ }^{42}$ Peter J Henning, 'The Organizational Guidelines: R.I.P.?' (2007) 116 Yale Law Journal Pocket Part 312.
} 


\section{Criminal sanctions for legal entity.}

The most frequently used sanction is a fine. ${ }^{43}$ Other sanctions include forfeiture, confiscation, restitution or even closing down of legal entities. Non-monetary sanctions available in some jurisdictions, such as withdrawal of certain advantages, suspension of certain rights, prohibition of certain activities, publication of the judgment, the appointment of a trustee and direct regulation of corporate structures.

As a comparison, France Penal Code recognizes several sanctions for legal entity, comprises of: ${ }^{\text {}}$

a) fine

b) dissolution (for the most serious offences: felonies, crimes against humanity, working and living conditions which infringe human dignity)

c) prohibition to exercise certain activities for a certain period (especially for the offences of torture and barbarity)

d) placement under judicial supervision

e) closure of the establishment for a given period

f) disqualification from public tenders

g) prohibition to make a public appeal for funds

h) prohibition to draw unauthorized cheques or to use payment cards

i) confiscation of the thing used or intended for commission of the offence or of the proceed of the offence

However, the offence should be committed "on their account by their organs or representatives", and as a consequence, a legal entity may not be held liable of its manager acts on his own behalf or in his own personal interest or if the offence is committed by an employee acting on his own initiative.

\section{Indonesia Case: Teoritical and Practical Reviews}

Indonesia recognized the criminal liability of legal entities only a very limited extent. Majority view argues that a legal entity as an "artificial" could not perform crime and owns nothing of criminal intention that led to criminal responsibility. Moreover, it is impossible for corporation to present physically before the courtroom as a defendant.

Under the existing Indonesian Penal Code, there is no provision that justified the criminal liability be imposed on legal person since the subject of criminal law is simply an individual (naturlijkee person). Thus, the current Penal Code cannot be used as a basis for criminal liability against the corporation, but only against its directors/management.

However, in further development a legal entity may be legally liable. The term "Corporations" began recognized as the legal person in the criminal law with the enactment of Law No. 7 Year 1955 on Investigation, Prosecution of Economic Crime and Justice. Afterwards, the recognition of a corporate criminal liability are scattered in various laws and regulations, such as:

1. Law No. 11/PNPS 1964 on Combating Subversive Activity.

${ }^{43}$ http://www.unodc.org, accessed on 20 February 2011. 
2. Law No. 38 Year 2004 on the Road ("Street Law").

3. Law No. 31 of 1999 on Corruption Eradication ("Corruption Act") as amended by Act No.20 of 2001 concerning Amendment to Law No.. 31 Year 1999 on Combating Corruption.

4. Law No. 32 of 2009 on the Protection and Environmental Management.

5. Law No. 8/2010 on the Prevention and Eradication of Money Laundering

Pursuant to the existing regulations, there are three forms of criminal responsibility in corporate crime based on existing regulations, which are charged to the corporation itself, as stipulated in Article 65 paragraph (1) and paragraph (2) of the Road.

Then, it can also be charged to the organ or corporate officials who did the act as leaders in committing a crime, [as stipulated in Article 20 paragraph (2) of the Corruption and Law. 31 of 2004 on Fisheries]

Then the next is likely to be charged either on a corporate board as the command or leader and also charged to corporations, such as in Article 20 paragraph (1) of the Corruption.

Indonesia Company Law No. 40 Year 2007 also stated that a company has a duty of care to respect statutes and regulations. It will be criminally liable for any breach thereof. ${ }^{4}$

Based on several laws, there is a tendency in Indonesia that a legal entity particularly a limited liability company or corporation could be held criminally liable.

\section{PT Newmont Case: Buyat Bay}

In 2004 there was an allegation against PT Newmont Minahasa Raya to have polluted Buyat Bay in North Sulawesi. The claim was made by the local residents stating that the gold mine wastes contained toxic levels of a variety of poisons and have caused illness in a local fishing village. As the result, six (6) executives were arrested. The civil claim for damages is \$543 million.

In January 2005, the claim was dismissed by the South Jakarta District Court on the ground of a settlement agreement between Newmont and local residents. Ness was released from all charges after almost 2 years of criminal trial. But in March 2005, Ministry of Environment filed a civil lawsuit for damages in the amount of $\$ 133$ million. In February 2006, the claim was withdrawn since Newmont agreed to pay $\$ 30$ million over 10 years; criminal charges against 5 executives were dropped, except the President Director, Richard Ness. Ness finally was cleared of all charges in April 2007.

In this case, the prosecutor in its indictment stated not only the representatives of Newmont (natural person) but also PT Newmont itself as legal entity or artificial person or corporate body have violated Law No. 23/1997 on Environmental Law.

\section{Closing Remarks}

It is true that the Indonesian Penal Code, stipulated by the Dutch in the early years of the 20th century, does not treat corporations as the subject of criminal law. However, a number of other laws have subsequently intro-

\footnotetext{
${ }^{44}$ See Article 3 of Law No. 40/2007 regarding Limited Liability Company.
} 
duced corporate criminal liability for specific offences. Thus, on the statutory ground, legal person may be held criminally liable for limited types of offences under several laws in Indonesia.

However, on the practical experiences, it is premature to conclude that the current criminal proceeding will result in a conviction of a corporate defendant. It would be more typical for such matters to be resolved outside the criminal process.

The Fafo report on Indonesia suggests that there is no uniform approach to attribution of liability and that it depends on the views of the individual judge. Nor is there agreement in professional or academic circles as to the criteria to be used in attributing liability. ${ }^{45}$

In the future revision of the Indonesian Penal Code, it is suggested to also include provision for corporate criminal liability. Then, the possibility to impose criminal liability against a legal entity is governed by the Indonesian Penal Code itself.

As for the types of penalties, local public opinion favors economic settlement or compensation, and criminal prosecution of the director likely would be perceived as a complication for foreign investment.

Civil lawsuits are not typically successful, except as a means to try to attract the public's attention in terms of an integrated public relations campaign to drive a political rather than judicial resolution.

\section{Bibliography}

\section{Books :}

Asia/Pacific Group on Money Laundering, "APG 2nd Mutual Evaluation Report on Indonesia", July 2008.

Apeldoorn, van L.J. Introduction to Legal Science [Inleiding Tot De Studie Van Het Nederlandse Recht]. Jakarta: PT Pradnya Paramita. 1986.

Chance, Clifford. Corporate Liability in Europe, January 2012.

Chen, Jianfu. Chinese Law: Towards an Understanding of Chinese Law, Its Nature and Development (1999).

Gobert, James and Maurice Punch. Rethinking Corporate Crime (2003) 59

Gardner, Bryan A. ed., Black's Law Dictionary, $2^{\text {nd }}$ Edition. St. Paul, Minn.: West Group, 2001.

Glasbeek, Harry. "Looking for Responsibility in the Corporate World or The Corporation's Multiple Personality Disorder", Directors' Personal Liability for Corporate Fault, Wolters-Kluwer, 2008.

Mueller, G. Mens Rea on the Corporation: A Study of the Model Penal Code Position on Corporate Criminal Liability, 1957.

Ramasastry, Anita \& Robert C. Thompson, Executive Summary on Commerce, Crime and Conflict: Legal Remedies for Private Sector Liability for Grave Breaches of International Law, Fafo.

45 Allens Arthur Robinson for the United Nations Special Representative of the Secretary General on Human Rights and Business February 2008. http://198.170.85.29/Allens-Arthur-Robinson-CorporateCulture-paper-for-Ruggie-Feb-2008.pdf, accessed on October 20, 2012. 
Robinson, Allen Arthur. "Corporate Culture as a Basis for the Criminal Liability of Corporation", UNSRSG, Feb 2008.

Utrecht, E. Introduction to Indonesian Law (Pengantar Dalam Hukum Indonesia), cet. 11. Jakarta: PT Ichtiar Baru and Sinar Harapan. 1989.

\section{Journals and Articles}

Black, Henry Campbell. Black's Law Dictionary, $6^{\text {th }}$ Edition. St. Paul, Minn.: West Publishing Co. 1990. Available at Black's Law Dictionary Free Online Legal Dictionary 2nd Ed, http://thelawdictionary.org, accessed on 19 October 2012.

Boisvert, Anne-Marie. Corporate Criminal Liability. University of Montreal. 1999. Available at www.law.ualberta.ca/alri/ulc/99pro/ecrliab.htm, accessed on October 20, 2012.

Carla, Manduchi. The Introduction of Corporate "Criminal” Liability in Italy, published 16/12/2010, available at http://esameavvocato.diritto, accessed on 22 October 2012.

Fohlin, Caroline. The History of Corporate Ownership and Control in Germany, November 2005, http://www.nber.org/chapters/c10271.pdf, accessed on 21 October 2012.

Harris, Ron. Transplantation of the Legal Discourse on Corporate Personality Theories: From German Codification to British Political Pluralism and American Big Business, 2007. Available at: http://www.papers.ssrn.com, accessed on 20 October 2012.

James, Nicholas. "Separate Legal Personality: Legal Reality and Metaphor", Bond Law Review: Vol. 5: Iss. 2, Article 6 (1993), available at: http://epublications.bond.edu.au/blr/vol5/iss2/6, accessed on 20 October 2012.

Jiachen, Liu. 'The Legislation and Judicial Practice on Punishment of Unit Crimes in China' in Eser, Heine and Huber (eds), Criminal Responsibility of Legal and Collective Entities (1999).

Naffine, Ngaire. Who are Law's Persons? From Cheshire Cats to

Responsible Subjects. The Modern Law Review Limited. Vol. 66 (May, 2003).

Nagy, Zoltan Andras. Some Problems of the Criminal Liability of Legal Entity in Criminal Dogmatics. Available at: www.law.muni.cz, accessed on 22 October 2012.

Nouel, Gide Loyrette. Criminal Liability of Companies, Lex Mundi Publication, 2008, www.gide.com, accessed on 21 February 2011.

Neuner. Robert. Respondeat Superior In The Light Of Comparative Law, 4 Lousiana Law Review. (1941). Available at: http://digitalcommons.law.lsu. edu/lalrev/vol4/iss1/13

Olteanu, Bogdan. Civil Liability in the Internal Law of the European Union Member States, available at http://www.juridicaljournal.univagora.ro, accessed on 20 October 2012.

Smith, Bryant. Legal Personality, Suspicions News Magazine, Vol. 12 No. 1, p.79-99, 80, accessed on www.antisyhster.com, October 21, 2012.

UNODC, Liability of Legal Person, www.unodc.org, accessed on 20 February 2011.

Webster, Noah. Webster New Twentieth Century Dictionary of the English Language Unabridged, $2^{\text {nd }}$ Edition. New York: Simon \& Schuster. 1983. . Merriam-Webster's Dictionary of Law. US: Merriam Webster, Inc. 1996.

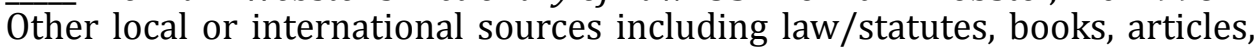
news, and electronics sources. 